M65 


\section{Soil Fertility}

A D D R E S S

MR. W. A. MISKIMEN

Delivered before the Ohio Canners Association at Cincinnati, December 11th, 1917

Published by Authority of Finance Committee of the

National Canners Association Washington, D. C. 

The real difficulty in preparing a short paper on Soil Fertility is to decide what can best be omitted. When we stop to consider that, as a matter of record, permanent agriculture has been discussed for over twenty centuries, that thousands are studying it in our colleges today, tilat books and bulletins treating of it exist by hundreds, it is a problem to select that material which will best combine interest and value. The subject is highly complex and so interningled with chemistry and mathematics that it is small wonder any present-day, practical farmers who really wish to become familiar with the science of their industry are overcome with the apparent amount of detail to be mastered, and, becoming discouraged, go back to the old routine, doing about what they see the other fellow doing. Taken as a whole, the farmers of this comntry now realize that on soil is not an incxhaustible mine from which crops can be taken indefinitely, without something being done to replace those things which the crops remove. It is fervently to be hoped that the farmers of the Middle West, the territory in which we are most interested, will inform themselves soon enough and think far enongh ahead to avoid wearing out their land. For while wornout land can be "brought back," that process is many fold more expensive, both in time and money, than the maintenance of present fertility. In addition to sucl maintenance, it is further to be hoped ancl expected that they will learn and apply methods resulting in a substantial increase ot the crops produced per annum from any given area. IIuch is to be done if these fond expectations are to be realized. There is a growing sentiment in favor of maintenance and increase of soil fertility, but the application of the idea in the Middle West is still in its infancy. As a matter of fact, things have been a little too easy. That is hardly the way to express it, either, as the farmer's life is far from being one of ease; but the land is still so good in some sections that comparatively abundant crops are the rule with no soil treatment except good tilling. Let us, rather, say that the farmer heretofore has been too easily satisfied. Formerly a very nominal crop supplied him with everything he lequired and a little something left over for a rainy day, but now, with the spread of broader education, the closer communication between rural and urban communities, his requirements and those of his family have multiplied. $\mathrm{He}$ is on the lookout for means to increase his resources, and thus be able to secure those benefits heretofore unconsidered, but now deemed necessities. Therein lies the way to reach a farmer's interest; for, like any other hnman, he can best be appealed to by means of that which affects his own welfare.

Some of you ma disagree on this next point, but, in my opinion, that which we are pleased to term modern, highly-developed civilization is founded not on necessity but on desire, and its achievements were brought about not because men needed more than they had but because they wanted more.

As mentioned above, the farmer is casting about for ways and means of increasing lis resources. His greatest matcrial resource, naturally, is his farm, and right there is certainly plenty of room for improvement. Relnctantly admitting to himself that he cannot secure something for nothing, many a good, practical farmer is trying to arrive at a system of permanent agriculture, but is groping in the dark. He has hopefully started reading articles in his farm vapers, only to stumble over unfamiliar ehemical or technical terms. II gazes at the analysis tags on sacks of commercial fertilizer, and they might as well be printed in a foreign language. It is just so much jalgon to him. If puts a carload of rock phosphate liere and some "Sure Shot Corn Grower" there, and quite likely has no idea whatever as to just what 
lis land really needs, either in treatment or in materials. Many farmers still think that a fertilizer is a fertilizer, regardless; and that when they spread so many dollars' worth on an acre they should secure several times that much in additional crop value the next year, also regardless. The natural retort in answer to all of the foregoing is that the farmer should study up on these things. He should get busy, if you please. Gentlemen, he is already busy. His working day is limited not ly time-clocks or factory whistles or office schedules, but by the number of lours of daylight, with a few more thrown in for good measure when climatic conditions or sickness require extra care for his stock. J'he tasks on a farm are never completed. It would be unreasonable to expect that the bulk of the present-day farmers will ever become soil experts or finished chemists. Not only must the research and experimental work be done for them, but permanent agricultural systems for alfierent conditions must be perfected and placed at their disposal, so that they will need give attention only to local details and minol differentiations in order to apply the one best suited to their respective farms. This work the agricultural schools and experimental stations are doing now, and doing it well. But while they are busy securing and classifying information, others must be at work carrying it in graphic; convincing and understandable form to the farmer working at lome. They must also help him in applying it to his own particular conditions or difficulties. In this part of the work each one of you has a distinct duty to perform, which we will mention again later.

Now with regard to the soil, plant life, and plant food, there are a few, simple facts and first principles which even the busiest farmer' should know, and while they are familiar to all of you, it might be well to recall them briefly to mind.

For purposes of illustration and comparison, let us consider a farm as a manufacturing establishment, just the same as a cannery, or watcl works, or any other factory. Think of the soil as the shop or workroom where such processes in the making of the plant as can be helped or retarded by the farmer are carried on. First of all, in order to secure the best results, this work-room must be in good mechanical and sanitary condition. That condition is brought about by proper drainage, careful tilling, and the application of sucl substances as may be necessary to counteract or neutralize unfavorable properties. These latter may be of two kinds-physical, as in a case where the soil is so compact and stiff as to limit tlie feeding range of the plant roots; or chemical, as in the case of so-called acid soils. It happens that one material, lime, helps to correct both of the above conditions. It not only improves the texture of a heavy soil, but also reduces the acidity of sour land, thereby greatly increasing the power of the legume crops to transform the insoluble organic nitrogen of the soil into soluble nitrate nitrogen, the form in which it becomes available for plant food. Bear in mind, however, that lime by itself merely improves the condition of the soil workshop. It acts as a stimulant and speeds up production of the finished article from the materials in the soil, but lime alone does not replace any of the materials which ordinarily become deficient by constant cropping. Therefore, lime, if improperly used, will materially hasten the ultimate ruin of the land. This is one of the various pitfalls which beset the way of a farmer who is poorly informed. Take land plaster, for instance, which is native calcium sulphate. At one time it was lieralded far and wide in some parts of this country as a fertilizer. Its promoters would mark the word "plaster" in large letters ili a field adjacent to some traveled highway and apply to the letters a l:eavy coat of the material. Then, when the grain crop or grass came on, the word "plaster" could be read in the heavier growth. As a matter of fact, this land plaster supplied no plant food whatever of commercial value. It did not even have the virtue enjoyed by lime, of being able to correct soil acidity. It was a stimulant, pure and simple, and in 
addition to hastening the deterioration of the soil, its continued use made the ground very hard and difficult of cultivation. There should always be held in mind a definite distinction between soil treatment which merely stimulates and that which maintains fertility while giving high yields.

Now, let us assume that our workshop in the soil is in first-class condition and has started to manufacture or produce. What is going on? Simply this: Certain raw materials are being put together and made ready for harvest in the form of corn, peas or whatever the crop may be. Will this process continue indefinitely simply by sowing seed and cultivating? It will not. Each time a crop is removed a certain portion of various substances is subtracted from the finite amount of these substances originally contained in the soil. The factory is using up its stock of raw materials in producing the finished goods, and those raw materials must eventually be replaced if the factory is to continue in successful operation.

This brings us to the question of plant foods. There are known to chemistry some eighty or more basic elements which unite in various ways to form many thousands of combinations or compounds of widely diverse character. For instance, sugar, starch, fats and alcohol are all composed of just three elements-carbon, hydrogen, and oxygen. Plants are composed of many compounds, but usually contain a total of only fifteen basic elements. Of these fifteen, five are said to be unnecessary to plant growth, leaving ten that are essential for that purpose. Three of the ten-carbon, hydrogen, and oxygen-are obtained by the plants from air and water. The remaining seven (with the exception of nitrogen in the case of the legumes, such as clover, soy beans, etc.) must be present in the soil, and, furthermore, must be in such form as to be available or capable of being taken up by the plant roots. The seven elements referred to are nitrogen, phosphorus, potassium, sulphur, calcium, iron and magnesium. It is interesting to recall that these seven elements constitute only about 5 per cent of the common agricultural plants, but, nevertheless, they are, under normal conditions, the limiting factor in the size of a crop. When any one of them is deficient in available form, the yield is reduced, as deficiency in one element cannot be remedied by surplus of another.

I will not take your time here to discuss the weight of each of these elements contained in 2,000,000 pounds of average soil, which is the meight commonly accepted for the top soil to a depth of $62-3$ inches on one acre, nor to figure the amount of each element removed by an average crop. Suffice it to say that sulphur, iron, magnesium and calcium are present in most soils to last for a very long period. Potassium, that which we ordinarily speak of as potash, is sometimes low, but not nearly as often nor to the extent that has heretofore been supposed. We may therefore say, speaking of general conditions, that nitrogen and phosphorus are the most extensively deficient plant foods on our Middle West soils. At any rate, they are the first to be depleted.

Our problem, then, of arriving at permanent soil fertility while securing good yields in the grain farning system resolves itself into this proposition: Provide proper drainage, good tilth, furnish the necessary substance to give the land reasonable stimulation and neutralize abnormal conditions, and by all means maintain or increase the supply of essential plant foods.

Furthermore, these things must be done at the least expense, for what interests us is not the gross but the net. One method might wroduce series of large crops, but be very costly to apply, and some other system giving smaller yield might show a much better profit. Realizing the grain farmers' growing need for information along these lines, Dr. Hopkins, of the University of lllinois, has given much time and attention to the subject. In his address before the Western Canner meeting last month he brought out, among many others, the following 
points: There are in operation in Illinois at present forty-two experimental fields, averaging about 20 acres each. Upon these fields there are being tried out, under the soil and climatic conditions found there, methods of enrichment which it is hoped will lead to the permanent maintenance and enlargement of the productive power of the land. Some of these fields have been in operation for many year's. From investigatious so far made, it is recognized that on the common soil types of Illinois and those of like character in other States three materials are needed to make them richer than they were in their virgin condition. The first of these is vegetable matter carrying nitrogen, and in practicable farming that must be home grown, first because the nitrogen is secured so much more cheaply that way than in commercial form, and, second, because the vegetable matter has great value in other ways. It helps retain water, prevents extremes of soil temperature, makes sandy soils more compact, and renders stiff clay land more friable; also its decomposition sets free products such a carbonic and organic acids, which dissolve additional plant food from the mineral part of the soil.

The second material needed is natural limestone, in its original state, except that it be crushed. Experience to date indicates that it should be reduced to a point where the largest pieces are about a quarter of an inch in diameter, in which case the total product would, of course, range on that size down to a fine powder. If ground too fine, there is liability of considerable loss through leaching.

The third material needed is phosphorus. This is carried in various forms - raw bone meal, steamed bone, acidulated bone, acid phosphate, basic slag, and ground natural rock. Without entering into any discussion as to the inlerent advantages or relative costs of the various forms, would simply state that ground natural rock is easily secured in the Middle West under any ordinary conditions, is inexpensive, and gives very good results over a term of years where used in connection with the vegetable matter mentioned above.

As a result of application of the above materials, allow me to quote some figures given by Dr. Hopkins which are representative of the results secured on various crops. These figures are for wheat, and are averages for a number of years. In making these tests the regular crop rotation ordinarily used in grain farming was followed on the entire field. On one part of the field everything was taken off each year, including stalks, straw, etc., and nothing returned. The average wheat yield on this was 13 bushels per acre. On the next part all residues of crops grown on that portion were returned. The yield was 20 7-10 bushels per acre. On the next part the residues were returned and limestone applied, producing $317-10$ bushels per acre. On yet another portion, furnished with residues, limestone and fine-ground rock phosphate, the average was 442-10 bushels per acre. In connection with the above, consider this: The work of preparing the ground, cost of seed, planting and whole care of the crop was tlie same for the 13 buslrel yield as it was for 44 bushels.

That brings up the question of land value or earning power as influenced by crop increase. Suppose, for instance, that a farm is averaging 40 bushels of field corn per acre and other crops in proportion. If the corn yield were brought up to 60 bushels, or, rather, if the vartous crops were increased by 50 per cent, the land value would not be iucreased by merely the same percentage, but would be practically doubled. It is the same old matter of overhead that we have always with us in our canneries. After the fixed expense is taken care of. Increased production in any business runs up the earning power very rapidly. You can make your own estimate as to what doubling the yield would do to land values, and it is conceded that the Middle West is producing for an average at present just about half what it is capable of producing. Fifty-eight years ago Abraham Lincoln commented on 
the discrepancy between a 50-bushel wheat yield which he knew to be possible and the United States average, which was 18 bushels. He held it a certainty that study and experimental work were the keys to greatly increased productivity. His opinion was sound and has stood the test of time. Now, gentlemen, it goes without saying that you, as canners, are vitally interested in the securing of continued good crops. Most of you are engaged to a large extent in preserving perishable products, and therefore must depend on land in a relatively small area surrounding each of your respective factories. If the producing power of that land decreases, the scope of your operations will also decrease, and at a rapid rate. Each canner may have an excellently constructed plant, equipped with the most advanced types of machinery, together with a force trained to high efficiency in the preserving of food products, but the whole organization stands helpless unless there are, existing and accessible, in quantities to match the normal factory capacity, the food products which are to be preserved. All of which come directly from the soil.

On the other hand, consider the benefits which would accrue to the canner in the case of substantial increase of general crop yields. The capacity of many canneries is limited by the amount of raw material that can be secured. In others, the material and the factory capacity are fairly well balanced. In most any case, however, this capacity could be easily enlarged and at minimum expense, as the main buildings, the executives, the sales force and the firm's commercial standing are assets which already exist, are paid for, and can usually accommodate additional business without strain. In other words, increased crop production in any section would not only increase earning power of the land at a compound rate, but it would have precisely the same effect on the canneries of that section. We are told that agriculture is the most independent occupation. In a way it is, and if Middle West soils were allowed to grow poor the farmers would be able to jog along and secure enough for food and clothes long after the canneries were forced to close up.

It has been pointed out that bankers, physicians, editors, teachers and ministers, having trained minds, should acquire correct and adequate understanding of the fundamental principles of soil improvement and exert their influence over those who are less able to secure such positive information, lest the lands become so impoverished as to support only the farmers themselves, who, of course, have the first right to the food they produce. The canner should be placed at the head of the list, for he can get closer to the farmer on matters agricultural than can anyone else. Work hand in hand with your county advisers. If your particular counties have no adviser at present, help get them. They are a paying inrestment. It was mentioned herein as the canner's duty thus to carry pertinent information to the farmers of his community. Duty is not the word. It is too abstract, too general. Duty is that which ought to be done. We all have duties which to a certain degree we do not perform. This is a necessity, and its performance is indispensable to the perpetuation of our business. Likewise it is a rare privilege giving us opportunity to secure for ourselves both intellectual and material benefits while doing our share to preserve and amplify the resonices with which nature has so liberally endowed our lands. 






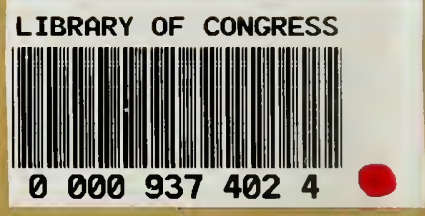

LIBRARY OF CONGRESS

0 0009374024

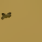




\section{LIBRARY OF CONGRESS}

||||||||||||||||||||||||||||||||||||||||||||||

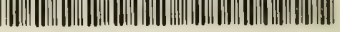

00009374024

Hollinger Corp. pH 8.5 